\title{
घ! Águas, cordas e cobras na cidade graciliânica
}

\section{Roberto SARMento Lima}

Professor Adjunto da Faculdade de Letras da Universidade Federal de Alagoas e Pesquisador no setor de Literatura Brasileira do Programa de Pós-Graduaçāo em Letras e Lingüistica da Ufal.

Resumo: A cidade, em Angústia, de Graciliano Ramos, é nāo apenas o espaço geográfico e social em que se desenvolve a história do atormentado Luís da Silva, à volta com a presença e onipresença do tempo da infância, mas é sobretudo o espaço simbólico que submete a forma narrativa e as lembranças do passado a uma organização verbal de movimentos indecisos, frouxos, fragmentados, de que a água, a corda e a cobra sāo imagens fundantes e determinantes da expressāo romanesca, em conflituosa interseçāo de sentidos.

Palavras-chave: Cidade; escrita; unidade; sujeito; fragmentação
Resumé: Dans le roman Angústia (Angoisse), de Graciliano Ramos, la ville n'est pas seulement l'espace géographique et social où se developpe I'histoire du tourmenté Luis da Silva, assailli par la présence et l'oniprésence du temps de son enfance; elle est surtout l'espace symbolique qui assujetit la forme narrative et les souvenirs du passé à une organisation verbale de mouvements indécis, flous, fragmentés dont l'eau, la corde et la couleuvre sont des images determinantes de l'expression romanesque dans une intersection conflituelle de sens.

Mots-clès: ville; écrit; unité; sujet; fragmentation 

As luzes da cidade

Não chegam às estrelas

Sem antes me buscar

("Lá vou eu", Rita Lee)

\section{Uma cidade toda feita contra Luís da Silva}

Os versos de Rita Lee, colocados em epígrafe a este artigo, lembram os lances dramáticos das últimas cenas de Angústia, nas quais Luís da Silva, narrador-protagonista, acusa, na cena que sobrevém ao crime, o peso e a aspereza do seu ato. Tudo na cidade, escura àquele momento, parecia fundir-se a sua fala mais íntima - isso porque, sendo escura e densa a alma da personagem, a realidade circundante aparece também na penumbra, em harmonização cromática adequada, em sintonia de planos aparentemente distintos. As luzes da cidade e o brilho das estrelas, a neblina (atmosfera estranha se se pensa em Maceió, espaço geográfico e cultural demarcado na narrativa), tudo era um conjunto de espessos entrelaçamentos, espécie de "escuridão leitosa", como avalia, em um expressivo paradoxo, Luís da Silva, prestes a cometer o assassinato: ${ }^{1}$

A lagoa próxima fervilhava de carapanãs. Como estaria Julião Tavares? Procurei distingui-lo, avancei a cabeça para o lugar onde supunha ter ele ficado. Um vulto quase imperceptível na escuridão leitosa. (p. 184, o grifo é meu)

Tudo se confunde no horizonte a partir de uma interpenetração e de um transtorno de coisas, por dentro e por fora de Luís da Silva. Este, como o eu lírico da poesia de Rita Lee, comanda o processo: as luzes da cidade só chegam às estrelas se antes o buscarem; a paisagem urbana em torno de Luís da Silva torna-se pesada porque ele está pleno de humores, ódios frementes. Assim, invertemse os dados da objetividade; assim, o que é normalmente pesado, compacto, apresenta momentaneamente sua corporeidade fluidificada, quase fantasmal, ou expres-
'As citações extraídas do livro Angústia foram feitas da $15^{3}$ edição da Martins/ Record, de 1975, da qual passo agora a servir-me para transcrição de passagens analisadas neste artigo. A expressão focalizada ao lado, por exemplo, aparece na página 184 da referida edição. 
sionisticamente deformada, rompendo-se a lógica dos objetos da realidade -

O corpo subia (p. 186)

— ou, em outro efeito imagético, contrário ao anterior,

Julião Tavares teria subido, ou a corda mergulhara no pescoço balofo? (p. 188)

Como se pode perceber, interior psicológico da personagem e exterioridade física, tudo o mais em volta, cruzam-se e implicam-se mutuamente - o estado mental de Luís da Silva está de cabeça para baixo, está revolucionado, fora do eixo, de modo a fazer a realidade parecer

2 Pode-se afirmar que, com a prática maciça do romance, a partir do século XVIII e ascensão da burguesia, essa forma literária assumiu definitivamente sua condição de escrita da cidade, marca de sua modernidade e de autonomia da literatura em geral quanto aos discursos escritos de prestígio social com os quais chegou a confundir-se, antes da transformação da narrativa em gênero por excelência dessa nova época cultural e histórica. contrariar princípios elementares da física - , o que significaria o desmantelamento do princípio naturalista de composição. Aliás, este seria o único livro de Graciliano Ramos em que isso se dá de modo mais explícito e derramado. Inversão súbita das coisas: o pesado (o corpo de Julião Tavares) flui e sobe, enquanto o flexível e leve (a corda) endurece, mergulha, enterra-se no pescoço da vítima, numa demonstração inequívoca de submissão da natureza à cidade. ${ }^{2}$

Mas essa interpenetração do exterior e do interior da personagem determinando-se mutuamente pode ser também julgada em seu movimento contrário. À primeira vista, o movimento do exterior e do interior mesclando-se em flagrante harmonia, dando provas de sua coerência e unidade composicional, pode ser, numa alteração de perspectiva, visto como o afastamento do homem das qualidades sensíveis da realidade em que ele se projeta. Nesse caso, o homem estaria contra a realidade, agindo apesar da realidade, numa interação negativa e destrutiva. No caso de Angústia, a cidade é o adversário de Luís da Silva, e, por isso, as coisas se passam dessa maneira. Isso lembra a frase do narrador Rodrigo S. M., de A hora da estrela, de Clarice Lispector, caracterizando a personagem Macabéa: “[...] limito-me 
a contar as fracas aventuras de uma moça numa cidade toda feita contra ela".

Uma declaração, pois, contra a capacidade de adaptabilidade do homem ao meio como também contra a natureza das coisas (como é possível o pesado flutuare o leve mergulhar? como podem as estrelas iluminar senão pedindo permissão às luzes da cidade, por intermédio do sujeito?). É que a modernidade é incompatível com a ingenuidade natural dos pastores árcades e a sacralidade dos deuses; como diria Vico, mesmo em sua tese que admite os corsi e os ricorsi, a "idade dos homens" é hostil à "idade divina" e à "idade heróica": "o narrador já não vive num mundo religioso. [...] Apesar da religiosidade e das regras de comportamento estético insufladas pela Contra-Reforma, a arte romanesca é pagã e crítica” (FERNANDES, 2000, p. 23).

Mas, em uma paisagem de crise de valores como a que surge no panorama da modernidade, não se pode confiar na onipotência do "sujeito do Iluminismo" (HALL, 2003, p. 10-12), em cujo âmbito Luís da Silva manteria o equilíbrio e a racionalidade (o que não é o caso, já que a realidade lhe aparece sempre maior do que ele, ameaçando-o, jogando-o de vez numa irremediável "angústia"). Aproxima-se ele, de certa forma, do "sujeito sociológico", em que, por um lado, se "era formado na relação 'com outras pessoas importantes para ele', que mediavam para o sujeito os valores, sentidos e símbolos do mundo que ele/ela habitava" (ibidem, 2003, p. 11), por outro, porém, ao contrário do que define Hall, para quem o sujeito sociológico teria uma "identidade [que] preenche o espaço entre o 'interior' e o 'exterior' - entre o mundo pessoal e o mundo público" (ibidem) —, Luís da Silva fracassa na interação com a comunidade, com a cidade em que vive e também nos desejos de ascensão social. Essa situação lhe provoca um lamentável e autocorrosivo estado psicológico, pois nada preenche esse vazio da alma que o próprio mundo, mesmo dando-lhe valores específicos (como a necessidade de escrever e se tornar conhecido), impõe, fragilizando-o.

Assim, esse romance parece dramatizar o con- 
flito entre as duas modalidades de sujeito, sem se resolver por nenhuma delas em particular. Em um caso, o sujeito do Iluminismo, o sujeito é idêntico a si mesmo por ação da razão, o que coibiria excessos de fantasia (afinal, Luís da Silva tem um projeto "iluminista": quer ser reconhecido como sujeito individual, como escritor, destacar-se pela sua ação no mundo); em outro, o sujeito sociológico, o sujeito ainda mantém certa essência interior, mas se transforma no contato com os objetos da realidade, numa interação entre o eu e o exterior, preenchendo as lacunas possíveis (Luís da Silva é impedido de suprir suas carências, mesmo assassinando o seu duplo). Aliás, a sensação de "preenchimento" é súbita, rápida e ilusória:

A obsessão ia desaparecer. Tive um deslumbramento. O homenzinho da repartição e do jornal não era eu. Esta convicção afastou qualquer receio de perigo. Uma alegria enorme encheu-me. Pessoas que aparecessem ali seriam figurinhas insignificantes, todos os moradores da cidade eram figurinhas insignificantes. Tinham-me enganado. Em trinta e cinco anos haviam-me convencido de que só me podia mexer pela vontade dos outros. [...] Julião Tavares estrebuchava. Tanta empáfia, tanta lorota, tanto adjetivo besta em discurso - e estava ali, amunhecando, vencido pelo próprio peso [...]. (p. 183)

Incapaz de restaurar-se, Luís da Silva assume logo a consciência de sua pequenez e fragilidade. O corpo arqueia-se, encolhe, diminui. O deslumbramento esmorece com as sombras da cidade:

Os amigos de Julião Tavares iriam julgar-me. [...] Que diriam os jornais? [...] Quem foi? Por que foi? Pimentel escreveria artigos horriveis. [...] Encolhime, o suor aumentou na friagem da noite. (p. 184)

No limite, Graciliano Ramos produz um herói que escorrega entre paradigmas de subjetividade, não se dei- 
xando prender por nenhum deles propriamente. Um sujeito incapturável, em movimento, tentando, às vezes ingenuamente, prender-se a um centro fixo, que é a sua fixação na escrita literária,

- Trago um romance entre meus papéis. Compus um livro de versos, um livro de contos. Sou obrigado a recorrer aos meus conterrâneos. Até que me arranje, até que possa editar as minhas obras. (p. 26)

para, logo em seguida, reconhecer o peso da realidade exterior, a cidade, sobre suas costas, implacável, destrutiva:

Mais tarde, já aqui em Maceió, gastando sola pelas repartições, indignidades, curvaturas, mentiras, na caça ao pistolão. (p. 26)

Esse exterior, em Angústia, é representado pela cidade, em razão da qual Luís da Silva criou uma nova identidade - já não carrega o nome pomposo da vetusta família rural, Pereira de Aquino Cavalcante e Silva, símbolo do velho mundo de que ele proveio, nem dispõe de espaços grandes e naturais (o exíguo quintal de sua casa é o último vestígio de natureza) para a restauração da situação anterior, no que fracassa retumbantemente - colocando-se a personagem entre resíduos de culturas distintas, porém subordinadas à cidade. ${ }^{3}$ Enfim, nem recupera a linhagem familiar nem o espaço em que se sentia mais adaptado, apesar das agruras sofridas. O antigo ainda lhe traz certo conforto; a cidade o esmaga:

Entro no quarto, procuro um refúgio no passado. Mas não me posso esconder inteiramente nele. Não sou o que era naquele tempo. Faltame tranqüilidade, falta-me inocência, estou feito un molambo que a cidade puiu demais e sujout. (p. 19, os grifos são meus)
${ }^{3} \mathrm{O}$ próprio Hall (2003) chama a atenção do risco que se corre ao absolutizar, para análise, um dos modelos de sujeito por ele propostos: "Deve-se ter em mente que as três concep̧̧ōes de sujeito [...] são, em alguma medida, simplificações " (p. 13); "Tentar mapear a história da noção de sujeito moderno é um exercício extremamente difícil. A idéia de que as identidades eram plenamente unificadas $\mathrm{e}$ coerentes e que agora se tornaram totalmente deslocadas é uma forma altamente simplista de contar a estória do sujeito moderno. Eu a adoto aqui como um dispositivo que tem o propósito exclusivo de uma exposição conveniente" (p. 24, os grifos são meus). 


\section{A roupa não faz o monge}

Tal visão, presente em Graciliano Ramos, poderia nos levar a pensar, por um lado, que aí está um remanescente do código romântico, ansioso pelo passado inteiro, o que não seria de todo inacreditável, visto que foi a partir do século XIX que se adensaram as relações entre a literatura e a cidade, das quais somos todos, afinal, herdeiros. Ao romance, forma emergente essencialmente crítica da cultura burguesa, foram destinados o registro da intimidade, a discussão dos conflitos e valores das classes médias em desfavor da aristocracia decadente, fazendo crescer a noção do individualismo e da subjetividade. $\mathrm{Na}$ impossibilidade, pois, de resolver na prática a quebra das antinomias kantianas, a solução encontrada foi submeter, no plano da filosofia e da estética, toda a realidade a um Eu absoluto, explicação de Fichte para a proposta da unidade entre o eu e o mundo. No dizer de Hall (2003), sob a categoria do "sujeito sociológico", esse contato interativo entre o eu e o mundo modifica a posição do sujeito; para o romântico Fichte, o Eu (a maiúscula faz toda a diferença) produziria uma idéia de mundo.

Com a descoberta da força vivificante da cidade, desde os românticos, a literatura nunca mais foi a mesma, nem naqueles tempos nem nestes em que estamos. A cidade nos cindiu, nos revelou a condição de seres precários, que, para sobreviver, precisam ter consciência das suas peculiaridades. Luís da Silva é um ser dilacerado porque insiste em se reconhecer, em ser reconhecido, em luta constante com o meio. É o preço da consciência, como se vê na passagem em que ele observa o movimento de uma livraria:

Passo diante de uma livraria, olho com desgosto as vitrinas, tenho a impressão de que se acham ali pessoas exibindo títulos e preços nos rostos, vendendo-se. É uma espécie de prostituição. (p. 7)

A unidade entre o eu e o mundo, que pela consciência não se dá - muito pelo contrário, só se revela em 
aspereza e contradições para quem tem o poder de refletir bem sobre essa questão - é, no entanto, a saída estilística, na vida e na arte, para o impasse criado. Unidade que se dá por elipses, por sombreamentos, por elisões. Por isso é que, desde a década de 1840, a moda européia marcou-se pela uniformidade e pelo monocromatismo: homens e mulheres se vestiam uniformemente, sem grandes atrativos, optando em geral por cores escuras, simulando neutralidade na aparência. O homem público é igual a todos em sua aparição social. A sombra e o avesso das cores dominam o vestuário e a sua conformação à cidade:

Oito e meia. Preciso vestir-me depressa, chegar à repartição às nove horas. Apronto-me, calça as meias pelo avesso e saio correndo. Paro sobressaltado, tenho a impressão de que me faltam peças do vestuário. Assaltam-me dúvidas idiotas. (p. 20)

Só através de detalhes e discretos sinais espalhados sobre a roupa e o corpo, através de um gesto, de um olhar, é que se podia descobrir um traço pessoal de gosto e de classe (SENNETT, 1988, p. 203-205), uma não-confessada interioridade, por isso imperceptível aos olhos dos outros cidadãos:

Ignoro quanto tempo fico assim. Provavelmente um segundo, mas um segundo que parece eternidade. Está claro que todo desarranjo é interior. Por fora devo ser um cidadão como os outros, um diminuto cidadão que vai para o trabalho maçador, um Luís da Silva qualquer. (p. 20, os grifos são meus)

A individualidade estava restrita a pequenas marcas, já que, fazendo parte de uma sociedade que prometia a igualdade e a liberdade, não se podia expor desabridamente o gosto pelo excêntrico. Aliás, o exótico devia estar apenas associado ao programa de uma literatura histórica e sedenta de alteridade cultural, que no Brasil foi representada pela corrente indianista. Fora, pois, do contexto nacionalista, a ordem era simular, disfarçar, atenuar as diferenças. Decorrência disso é que a preferência pela noite, nos poemas e nos 
textos narrativos românticos, tornou-se a tradução estilística do desejo de unidade, pelo qual tudo se mistura e os sentimentos se imiscuem e se interpenetram. Na cidade, correspondentemente, os homens e mulheres mais velhos, que já tinham ultrapassado a fase da juventude, buscavam não se expor muito à luz diurna. Nesse contexto de monotonia de colorido, era sinal de provincianismo o mostrar-se ruidoso, colorido, extravagante:

As diferenças entre as vidas cosmopolita e provinciana estavam envolvidas nesse gosto pelo anonimato. Nos anos 1840, tornara-se mesmo um sinal de maneiras cosmopolitas da classe média, ou então o desejo de urbanidade entre os provincianos [...]. A idéia de povo começou na geração de Herder, e sobreviveu quando os românticos contemporâneos de Herder saíram de cena - o povo sempre rural ou aldeão, e a cidade cosmopolita sendo sempre antipovo. (SENNETT, 1988, p. 206)

Luís da Silva é um homem da cidade. Sua separação do mundo rural, de onde proviera, obrigara-o a reduzir-se a Luís da Silva, a esconder-se, a apagar a distinção que o nome de família poderia infundir. A marca de distinção do velho mundo aristocrático estava, antes de tudo, concentrada no nome: Trajano Pereira de Aquino Cavalcante e Silva. Eis então uma redução do nome, da singularidade: em troca, a espessura do anonimato, das cores cinéreas que recobrem monotonamente todo o romance, fazendo de Maceió uma cidade singular, de matizes penumbristas. Daí - obsessão pela unidade - a preferência pelas manchas, pelas sombras, pela "escuridão leitosa", numa fusão do exterior com o interior psicológico,

Uma chuvinha renitente açoita as folhas da mangueira que ensombra o fundo do meu quintal, a água empapa o chão, mole como terra de cemitério, qualquer coisa desagradável persegue-me sem se fixar claramente no meu espírito. Sinto-me aborrecido, aperreado. (p. 13, os grifos são meus) 
a ponto de Luís da Silva desejar fundir-se à terra, misturar-se ao húmus, retornar ao ventre úmido, escuro, em que tudo, indistintamente, perde clareza e diferenciação:

Uma lentidão de lesma. Subitamente notei que o corpo subia e balançava. Passei rápido a corda pelo galho. Outra volta, outras voltas, um nó que me levou o resto da energia, e fiquei ali arquejando, desmanchando-me em suor. Desejaria achatar-me, confundir-me com as coisas moles e úmidas que os meus dedos tinham esmagado sobre a casca da árvores. (p. 188-190, o grifo é meu)

Teria Graciliano Ramos operado, nessa trilha de visitação romântica, um desvio do seu projeto escritural, marcado pelo registro frio, mais objetivo e contido da realidade, mesmo aquele no âmbito da análise psicológica? Paulo Honório, de São Bernardo, após o suicídio de Madalena, não se desvencilha da pragmática da vida cotidiana mais elementar, a não ser quando, no auge do processo do autoconhecimento, vai se desligando das ações mais comezinhas para voltar-se para a raiz do seu desastre doméstico, momento em que, já no final do romance, se vê como alguém que tem "um coração miúdo, lacunas no cérebro, nervos diferentes dos nervos dos outros". Mas nem assim esse atormentado narrador perde o contato com a realidade, como quem tenta recuperar a racionalidade: "Fecho os olhos, agito a cabeça para repelir a visão que me exibe essas deformidades monstruosas".

\section{Um narrador dépaysé}

Em Angústia, Luís da Silva não se reabilita dos excessos nervosos e psíquicos; aqui, a narrativa, ao contrário da de São Bernardo, já nasce com os sintomas do esgotamento nervoso e da falta de energia, à moda do processo escritural e interpretativo romântico, com sua longa noite interna, nublada e espessa, 
Levantei-me há cerca de trinta dias, mas julgo que ainda nāo me restabeleci completamente. Das visões que me perseguiam naquelas noites compridas umas sombras permanecem, sombras que se misturam à realidade e me produzem calafrios. (p. 7)

além do que o narrador não se envergonha de sua perversidade e autoflagelação psicológica, informadas por sentimentos e aspecto físico que, no texto, aparecem como naturais à configuração dessa personalidade:

Penso no meu cadáver, magríssimo, com os dentes arreganhados, de olhos como duas jabuticabas sem casca, os dedos pretos do cigarro cruzados no peito fundo. (p. 9)

Numa narrativa em que o eu narrador sofre cisões e perdas, aparecem compensatoriamente símbolos de alargamento, fecundidade, amplidão, circularidade. Será então por isso que, na economia dessa narrativa, se tornam freqüentes as alusões a águas, cordas e cobras, ora como termos que valem pela sua denotação, ora como metáforas que indiciam pensamentos, afetos e atitudes, em meio à dureza e aspereza com que Luís da Silva analisa o seu estado e modo de ser?

Em geral, na Índia, considera-se este elemento [as águas] como o mantenedor da vida que circula através de toda a natureza, em forma de chuva, seiva, leite, sangue. Ilimitadas e imortais, as águas são o princípio e o fim de todas as coisas da terra. [...]. A imersão nas águas significa o retorno ao pré-formal, com seu duplo sentido de morte e dissolução, mas também de renascimento e nova circulação, pois a imersão multiplica o potencial da vida. (CIRLOT, 1984, p. 62-63)

A narrativa não segue uma linha temporal bem marcada mas se desenvolve ao sabor da mistura do presente opressivo com as lembranças do passado, não menos opressivas — onde a "água" e a "cobra", a partir de 
então transformadas em imagens obsessivas em toda a composição textual, criam superposições de denotações e conotações:

O culto das serpentes e dos gênios das serpentes, na Índia, está vinculado às águas. As serpentes são poderes protetores das fontes da vida e da imortalidade, bem como dos bens superiores [...] psicologicamente é um sintoma da angústia e expressa uma animação anormal do inconsciente, quer dizer, uma reativação de sua faculdade destruidora. (CIRLOT, 1984, p. 521-523)

O protagonista, apresentando-se como um homem de trinta e cinco anos já vivendo na cidade, não consegue, no entanto, esquecer que o que ele é resulta de sua vivência de uma criança que foi forçada pelo pai a mergulhar repetidas vezes nas águas do poço, em uma fazenda arruinada. Daí a ambigüidade de símbolos como água e cobra espalhados ao longo do texto. A água, como pretendo depois destacar, vai unir-se a todas as reminiscências e aos movimentos internos da consciência de Luís da Silva, no presente. Lembranças do passado imiscuem-se no presente narrativo; cruzam-se os dois tempos, interrompendo o fluxo desse presente, através de semelhanças entre imagens que povoam, quase que simultaneamente, esses dois tempos do enunciado:

Estremeci. Os meus dedos contraíram-se, moveram-se para Julião Tavares. Com um salto eu poderia agarrá-lo.

Pensei em Seu Evaristo e na cobra enrolada no pescoço do velho Trajano. Parei no meio da sala, aterrado com a imagem medonha que me apareceu. O pescoço do homem estirava-se, os ossos afastavam-se, os beiços entreabriam-se, roxos, intumescidos, mostrando a língua escura e os dentinhos de rato. (p. 74)

Que relação há, pois, entre os dedos curvos e contraídos de Luís da Silva, do jeito como são surpreendidos no presente da enunciação, e a evocação da imagem também curva da cobra enrodilhada no pescoço do avô? É 
esse formato curvilíneo que dirige o tempo todo o trajeto do narrador-protagonista. Por isso é que, mesmo distante do passado e do ambiente da infância, Luís da Silva anda pela cidade, com sua postura arqueada, como um estranho de si mesmo, não se reconhecendo como um homem:

Pensam que vou ficar assim curvado, nesta posição que adquiri na carteira suja de Mestre Antônio Justino, no banco do jardim, no tamborete da revisão, na mesa da redação? Pensam? Procuro ajeitar as vértebras, mas as vértebras parecem soltas, presas apenas por um fio [...]. (p. 113; o grifo é meu)

Campo e cidade fundem-se no corpo de Luís da Silva: a sinuosidade do andar, a frouxidão dos músculos e dos gestos, a soltura das vértebras. Como uma cobra que se arrastava no copiar da casa do avô, Luís da Silva arrasta-se na cidade indiferente:

[as vértebras] Resvalam pouco a pouco, e ao cabo de vinte minutos de exercício penoso o meu corpo toma a configuração de um arco. A cabeça pende, como se procurasse dinheiro na calçada, e a camisa faz pafos no peito. (p. 113, o grifo é meu)

A mudança do campo para a cidade é, ao mesmo tempo, uma alteração geográfica na vida de Luís da Silva e uma mudança de humor, mas não uma solução de continuidade entre esses dois espaços, como se poderia supor. Campo e cidade não estão em pólos opostos, pois ambos têm a mesma carga de violência capaz de provocar, na personagem, sentimento de desenraizamento; apenas se dá, nessa passagem de um lugar para outro, a atualização das imagens dominantes no romance. Enquanto vivia no ambiente rural, o medo e a insegurança o caracterizavam, deixavam-no entre tímido e assustado, embora, mesmo desse jeito, se sentisse um tanto protegido. Nessa confusão de sentimentos, reconhecendo desde cedo a opressão, chega a desejar a morte do próprio pai: 
Que ia ser de mim, solto no mundo? Pensava nos pés de Camilo Pereira da Silva, sujos, com tendões da grossura de um dedo, cheios de nós, as unhas roxas. [...] Eu não podia ter saudade daqueles pés horriveis, cheios de calos e joanetes. [...] Desejava em vão sentir a morte de meu pai. (p. 17)

O avô, o pai, as cobras que passeavam à toa pelo pátio da fazenda eram figuras ameaçadoras, que o intimidavam e que o submetiam:

Quando eu ainda não sabia nadar, meu pai me levava para ali, segurava-me um braço e atiravame num lugar fundo. Puxava-me para cima e deixava-me respirar um instante. Em seguida repetia a tortura. (p. 14-15)

A experiência infantil converte-se, graças à mudança de ambiente, na outra ponta da questão, não menos cruel, em que Luís da Silva surge como aquele que agora ameaça e constrange, ao menos idealmente, na mesma medida em que se sente emparedado, tolhido. Relembrando os mergulhos involuntários no poço, pensa, por associação, na arredia Marina, que ora o enfeitiça, ora o repele; e, nesse devaneio, mistura violência com erotismo:

Se eu pudesse fazer o mesmo com Marina, afogála devagar, trazendo-a para a superfície quando ela estivesse perdendo o fôlego, prolongar o suplício um dia inteiro... (p. 15)

Como ele mesmo afirma depois, a água do banho - e aí ressurge a imagem da água do poço, agora em forma atualizada - tanto serviria de instrumento de martirização do outro quanto, em direção oposta, mas contígua em seus sentidos textuais, manteria a capacidade de estimulação sexual. Na cena em que, colado à parede do banheiro da vizinha, ouve sons de água e da torneira do banho, Luís da Silva mistura de novo os sentidos de tortura ("esfolar-se") e de sexo ("me excitava"):

A espuma entrando nos sovacos e nas virilhas fazia um gluglu que me excitava extraordinariamente. 
Parecia que Marina queria esfolar-se. Imaginava-a em carne viva, toda vermelha. Imaginava-a branquinha, coberta de uma pasta de sabão que se rachava, os cabelos alvos, como uma velha. Essas duas imagens me davam muito prazer. (p. 128)

Assim, o poço da infância e a água que corre do chuveiro de Marina superpõem-se e, conforme a linguagem freudiana, condensam-se. O pensamento de Luís da Silva é feito por associações contínuas, por analogias entre o passado e o presente, entre o campo e a cidade, entre o prazer e o desprazer, sem que os pólos das antinomias se distingam em tempos diversos de apresentação. Tudo se deixa envolver nesse amálgama representado, como observei no início deste artigo, pela "escuridão leitosa" - uma sinestesia que guarda em seu interior a indissolúvel contradição entre o escuro/áspero e o claro/mole. Os fragmentos se encontram e se harmonizam, reclamam-se mutuamente; e aquilo que pode, na superfície do texto, parecer estranhamento e afastamento das coisas entre si nada mais é do que uma espécie de manifestação fenomênica de uma ordem dos seres numa sociedade que elegeu o incapturável como seu elemento diferenciador. Algo nos escapa desde sempre, e morremos sem alcançá-lo, seja porque a propaganda exagerou ao decantar as qualidades do produto, seja porque o real nunca coincide com o ideal, sob trabalho da reflexão dialética. Afinal, tudo é sombra.

Desde o romantismo, aliás, não se fala de outra coisa, em versões que se tangenciam: "A filosofia é saudade ânsia de sentir-se em casa em todos os lugares”, disse Novalis; "o que é sólido desmancha no ar", sentenciou Marx. Parodiando Novalis, arrisco-me a dizer que Luís da Silva não se sente em casa em lugar nenhum, não porque não sinta de algum modo saudade desse passado - suas lembranças são sempre amargas, torturantes, mas também compensatórias -, mas porque é o dépaysétípico, sente-se mal em todos os lugares. Enfim, a dispersão, o isolamento entre as partes, a fluidez, o estranhamento entrevistos nessas declarações valem por sintomas - não são lugares ontologicamente de- 
marcados e incomunicáveis, nem têm consistência material autônoma (aliás, esse é o disfarce ideológico que mantém a sociedade capitalista de pé) - - uma vez que a vontade geral era acusar a rispidez dos tempos industriais, que lançou para sempre o homem no "livro do desassossego". A consciência da fragmentação, no entanto, não significa exatamente a separação entre as coisas, homens e palavras, mas uma espécie de vivência que assim se dá e se oferece, pois

[...] a vida social é, em sua realidade fundamental, una e indivisível, uma rede inconsútil, um processo único, inconcebível e transindividual, em que não há necessidade de se inventarem modos de conectar os fatos da linguagem e as convulsões sociais ou as contradições econômicas porque, nesse nível, eles nunca estiveram desligados uns dos outros. O reinado da separação, da fragmentação, da explosão dos códigos e da multiplicidade das disciplinas não passa da realidade da aparência: ela existe, como diria Hegel, não tanto em si mesma, mas para nós, como base lógica e lei fundamental de nossa vida diária e da experiência existencial no capitalismo tardio. (JAMESON, 1992, p. 36-37; os grifos são do autor)

O aparecimento, em Angústia, de um clichê romântico como "escuridão leitosa" remete a uma tradição escritural e ao mesmo tempo empresta unidade a toda essa narrativa, por sua vez uma página dessa grande narrativa que é a narrativa moderna, pois a ordem seqüenciada das coisas não importa, antes a sua qualidade é que sobressai. ${ }^{4}$

\section{As palavras-coisas da narrativa}

Logo na segunda página do romance surpreendemos o protagonista brincando com associações entre palavras que nascem da semelhança fônica com o nome Marina: ar, mar, rima, arma, ira, amar. Um crítico de compleição formalista encontraria aqui os truques essenciais de reconhecimento do literário e valorizadores da escrita literária; um crítico marxista associaria o procedimento à alienação e
${ }^{4}$ Desde já quero reforçar a intimidade entre a literatura romântica e a moderna, enfatizando que a revolução artístico-literária operada com a ascensão da burguesia, influindo nos rumos do gosto e das atitudes escriturais, não conheceu ai seu corte definitivo, ao menos na sensibilidade e na configuração dos princípios da produção literária vigentes até o momento. $\mathrm{O}$ individualismo, que resultou em uma linguagem expressiva, pouco afeita à lógica convencional, ainda nos atinge, portanto. Por isso podemos fazer recuar a modernidade ao romantismo, quando se deu uma alteração nos costumes e nos protocolos de leitura e escrita da literatura, tal como é entendida ainda hoje, a despeito de tanta revolução formal nessa prática significante e área do conhecimento. 
à fetichização da vida social, tomada de súbito em sua fragmentariedade em meio à unidade de visão; já um crítico psicanalista estudaria o caso Luís da Silva buscando sentidos latentes no manifesto dessa sintaxe. Segundo penso, Graciliano Ramos dá, logo de entrada, a pista para a avaliação estética do romance, sem que se descredenciem os sentidos críticos há pouco arrolados. Embora Luís da Silva diga que tais associações são "coisas absurdas", o desenvolvimento da narrativa o desmente: "ar", "ira", "amar", "arma" são signos operantes no texto. Servindo-se de uma figura como a litotes, pela qual se nega para afirmar,

Penso em indivíduos e em objetos que não têm relação com os desenhos: processos, orçamentos, o diretor, o secretário, políticos, sujeitos remediados que me desprezam porque sou um pobrediabo. (p. 8, o grifo é meu)

Ou seja: ao dizer que não, o narrador na verdade confirma a íntima relação de palavras-coisas, como "arma" e "ira", com os sentidos mais recônditos do texto. Isso soa como truque de leitura (o mesmo de que Olavo Bilac se serviu para dizer que seu poema era "arte pura, inimiga do artifício", sendo sua prática escritural a prova maior, sim, do artifício e do artificialismo parnasianos). Na verdade, apesar de Luís da Silva declarar o contrário, palavras e desenhos se relacionam, assim como se relacionam de modo imediato as imagens do passado e as do presente enunciativo: a água do poço e a água que corre no banheiro de Marina, a cobra que sufoca o pescoço do velho Trajano e a corda (tão ameaçadora quanto) que serve para enforcar Julião Tavares. Apenas a cidade, que determina a configuração do dizer, a sua sintaxe e a organização das imagens, vai operar a transformação do natural no cultural, separando e segmentando os planos semânticos de onde emergem tais palavras. Através desse expediente, o narrador faz que a cobra enrodilhada no pescoço do avô Trajano reapareça - na paisagem urbana - como corda, aquela que vai enrolar-se no pescoço de Julião Tavares, em uma superposição de sentidos, unidos, porém, pela idéia de morte: 
A corda enlaçou o pescoço do homem, e as minhas mãos apertadas a fastaram-se. (p. 182)

Da mesma forma, fazendo as palavras e símbolos o caminho de volta, os canos da casa de Luís da Silva são as mesmas cobras da fazenda de Trajano, pois em ambas as expressões se concentram as idéias recorrentes de sexo e morte. Como sexo, vale a função fálica do cano, seu formato, aparência e função:

Punha-me a passear pelo corredor, olhando as biqueiras dos sapatos, os tijolos gastos, o rodapé vermelho da parede úmida. Por ali passava um cano. Algumas porcas das juntas estavam mal apertadas e por elas a água esguichava, formando poças no tijolo gasto. O cano estirava-se como uma corda grossa bem esticada, uma corda muito comprida. (p. 88)

Já a sugerir os conteúdos da morte e da violência, o cano aponta para sua qualidade de arma, não, porém, em seu sentido próprio, como cano com que se pode ferir, mas como corda, outra vez evocada, em mais uma associação, nessa conjunção e superposição de elementos denotativos e conotativos:

Mas aquele [cano] comprido demais, pregado ao chão, não tinha jeito de arma: parecia uma corda estirada. (p. 90)

No mais, a envolver e confundir tudo, impera a ação onipresente das sombras da cidade, da fuligem, da escuridão leitosa - em síntese, tudo o que, por essa impressão visual, levou Candido, referindo-se a esse romance, a chamá-lo de "livro fuliginoso e opaco" (CANDido, 1992, p. 34). Por essa imagem, tudo é e não é.

Metido nessa atmosfera opressiva, Luís da Silva confirma, na prática simbólica da escrita de primeira pessoa, as experiências de negatividade e de desestruturação que o acometem vida afora, como se estivesse prenunciando o que estaria por vir, e o que já aconteceu, no campo 
e na cidade: a insatisfação, a falta de ar, a sensação psicológica de sufocamento, o crime, a angústia.

Como penso que as associações entre palavras não são meros jogos formais, vejo as palavras transformaremse em coisas e fatos, numa quebra total da arbitrariedade do signo: eis então que o narrador mata o rival, Julião Tavares, movido pela ira, munido de uma arma, a corda, por amar uma mulher que é objeto do desejo de dois homens. Como na literatura romântica, amor, traição e morte juntam-se em movimentos associativos. O processo de construção da sintaxe do texto e das relações entre personagens se dá por associação cujas fontes primárias são as pistas verbais estrategicamente plantadas no início de Angústia. É por esse mesmo artifício que a pronúncia de palavras como cobras e cordas se alterna ao longo do texto: ambas as imagens, independentemente de se encontrarem no campo ou na cidade, insinuam a marca da segregação e da morte:

Certo dia uma cascavel se tinha enrolado no pescoço do velho Trajano, que dormia no banco do copiar. Eu olhava de longe aquele enfeite esquisito. A cascavel chocalhava, Trajano dançava no chão de terra batida e gritava: - "Tira, tira, tira". (p. 73)

Já na cidade, como fiz ver antes, o rolo de corda que Luís da Silva ganha de seu Ivo torna-se, por trânsito de similaridades, um ser vivo, sinuoso e ameaçador como uma cobra:

Aproximei-me da mesa, desenrolei a peça de corda. Mas, com um estremecimento, larguei-a e meti as mãos nos bolsos, indignado com o caboclo:

- Retire isso daí, Seu Ivo. Que diabo de lembrança foi essa? (p. 137)

Como as similaridades são o recurso estilístico fundamental em Angústiae, mais do que isso, o processo condutor dos movimentos do enredo, ainda que aparentemente díspares, a corda, nessa relação, lhe aparece como símbolo de morte e do interdito, a ponto de a coisa nem mesmo poder ser nomeada: 
- Não quero. Tire isso depressa.

Evitava dizer o nome da coisa que ali estava em cima da mesa, junto ao prato de Seu Ivo. Parecia-me que, se pronunciasse o nome, uma parte das minhas preocupações se revelaria. (p. 137)

Que preocupações seriam essas? Possivelmente trata-se da ideação do crime que estava por cometer e de todos os símbolos, dispersos no texto, a lembrar isso, por zelo máximo de coerência imagética desse narrador. Por isso, prosseguindo a cena, a corda parece ser mais do que uma corda; assim como o cano, que é mais do que um cano, a corda é uma arma e, magicamente, tem vida própria, como uma serpente:

Enquanto estivera dobrada, não tinha semelhança com o objeto que me perseguia. Era um rolo pequeno, inofensivo. Logo que se desenroscara, dera-me um choque violento, fizera-me recuar tremendo. Antes de refletir, tive a impressão de que aquilo me ia amarrar ou morder. (p. 137)

A mistura das imagens e a conversão de uma coisa na outra ou, ainda, a conversão de um espaço no outro eis aí o princípio formal de Angústia, o que confere movimento ao romance - , são determinadas, conforme anunciei desde o início deste estudo, pela sintaxe da cidade, que, desde o romantismo, se tornou linguagem fundante. Se Luís da Silva tivesse vivido apenas no campo, o processo de narração decerto se desenvolveria diferentemente: sua visão, apesar de também negativa no meio rural, seria, no entanto, mais afeita à realidade natural dos objetos. Por exemplo, a cobra enrolada no pescoço do velho Trajano era, de longe, para o menino que observava, um "enfeite esquisito", como afirma o narrador denunciando um engano da vista, mas, ainda assim, não deixaria de ser uma cobra, sem dúvida, já que, nesse ambiente, esse animal é comum e o menino Luís assim depois entendeu. Na cidade, porém, mesmo estando perto do objeto, um rolo de corda era uma serpente enrodilhada, pronta para atacar, o que provocou o medo 
injustificável do Luís da Silva adulto, reação incompreensível ao menos para seu Ivo. Isso porque a cidade é uma "escuridão leitosa", um emaranhado de coisas, um torvelinho, que impede a delimitação clara dos objetos. Tal configuração se estende à compreensão do anonimato entre as pessoas nas ruas da cidade; a experiência urbana torna os indivíduos difusos, mutuamente estranhos:

O mundo é empastado e nevoento. Súbito uma coisa entre mil nos desperta a atenção e nos acompanha. Não sei se com os outros se dá o mesmo. Comigo é assim. Caminho como um cego, não poderia dizer porque [sic] me desvio para aqui e para ali. (p. 123)

É essa estranha geografia que faz estranhas as pessoas. Por isso as associações parecem não ocorrer, já que tudo parece "naturalmente" separado e isolado, a não ser que se procure o íntimo das coisas. $O$ efeito próximo disso é que ocorre certa letargia, certa falta de energia, certa abulia:

Nenhum desejo de ir aos Martírios, subir o morro do Farol e escutar os tipos que se encostavam ao balcão sujo e gorduroso da bodega. Apalpei a carteira vazia, meti os dedos nos bolsos miúdos, vazios. Sentia-me incompleto e sem ânimo de me aventurar sozinho por aquelas ruas esquisitas. Sentia-me fraco e desarmado. (p. 112, o grifo é meu)

Assim, é natural pensar em uma estética da cidade. O discurso é aquilo que fragmenta e desune os seres e, ao mesmo tempo, faz refletir sobre as associações, num ato de lucidez que deve constituir o pensar sobre a própria construção literária. Um pensamento que inicialmente é um "vagabundear" sem maiores interesses e, aos poucos, se volta para si próprio nomeando-se, cedendo ao fatal reconhecimento de sua fraqueza:

Ponho-me a vagabundear em pensamento pela vila distante, entro na igreja, escuto os sermões e 
os desaforos que Padre Inácio pregava aos matutos [...] Vejo a figura sinistra de Seu Evaristo enforcado e os homens que iam para a cadeia amarrados de cordas. (p. 15)

É o Luís da Silva da cidade que avalia o Luís da Silva do meio rural. Acrescido da visão da cidade, seu pensamento embaralha-se contorcido:

Lembro-me de um fato, de outro fato anterior ou posterior ao primeiro, mas os dois vêm juntos. E os tipos que evoco não têm relevo. Tudo empastado, confuso. Em seguida os dois acontecimentos se distanciam e entre eles nascem outros acontecimentos que vão crescendo até me darem sofrível noção de realidade. (p. 15)

\section{Um quintal privilegiado na cidade}

$\mathrm{Na}$ cidade, as imagens perdem nitidez e marca identitária própria. Cada pedaço de realidade não se conecta com o outro: são estilhaços de um todo que parece não ter sentido para a personagem; daí o uso preponderante, nesses casos, de uma sintaxe coordenada, em uma série verbal cujos termos não se destacam uns dos outros, mas dispõem-se sem nexos efetivos entre eles a marcar uma possível relação de objetos que se dispõem sem relevo ou autonomia:

Debruçava-me, olhava os paralelepípedos, a sarjeta, o poste de ferro, os arames, a calçada da casa à esquerda. Virava-me para a esquerda. O outro lado não me interessava. Uma pancada no postigo, e recomeçava o passeio. Nova demora na sala de jantar. Coçava a barriga do gato, que se espreguiçava, estirava as pernas. Sem-vergonha, parecia mulher. O quintal estava escuro. Por cima das árvores havia claridade, até se enxergava, a distância, um anúncio que se podia ler; mas perto do chão era aquele pretume. Fastidiosa música de grilos, certamente no canteiro das hortaliças. (p. 41)

Nesse emaranhado de coisas que aparentemente 
não mostram sua importância ou necessidade no interior do texto - o olhar do narrador ou do leitor não se detém em nada em especial ("paralelepípedos", "sarjeta", "poste de ferro", "calçada" parecem estar aí à toa, sem influir na composição da descrição) - , eis que avulta o quintal, que representa, para Luís da Silva, o ponto de interseção entre o campo e a cidade. É para lá que ele vai quando volta do trabalho, quando quer ler, pensar em literatura, desanuviar-se, escapar, sair da cidade, voltar a ser ele mesmo.

Em janeiro do ano passado estava eu uma tarde no quintal, deitado numa espreguiçadeira, fumando e lendo um romance. O romance não prestava, mas os meus negócios iam equilibrados, os chefes me toleravam, as dívidas eram pequenas

- e eu rosnava com um bocejo tranqüilo:

- Tem coisas boas este livro. (p. 31)

No quintal, Luís da Silva pensa em Marina porque, pelo menos aí, a cidade parece não interferir destrutivamente no seu pensamento, o que o leva a manter assim a sua inteireza:

Pensei nas minhas entrevistas com Marina, alta noite, no quintal. Certamente ela havia esquecido aquilo, mas eu me lembrava de tudo muito bem. As formigas rendilhavam as folhas. Um grilo saltava no canteiro. A iluminação da cidade chegava ali muito reduzida. (p. 115, o grifo é meu)

A cidade não entra definitivamente no quintal; resta saber se o quintal é vitorioso no enfrentamento da cidade, que dirige a narrativa, o olhar do narrador, a direção das ações das personagens. Pois, como diz o próprio narrador, "Afinal, para a minha história, o quintal vale mais que a casa" (p. 37). Fora desse espaço, Luís da Silva volta a ser inseguro, estranhando a si próprio, como o demonstra uma passagem em que se encontra com Julião Tavares na Rua do Sol, após uma festa de arte realizada no Instituto Histórico de Alagoas. Desprotegido na rua, Luís da Silva desorienta-se, vê-se estilhaçado: 
Encolhi os ombros, olhei os quatro cantos, fiz um gesto vago, procurando no ar fragmentos da minha existência espalhada. (p. 43)

Tal visão acomete a percepção de Luís da Silva, que, numa síntese primorosa, reflete, a certa altura da narrativa, sobre os objetos à sua volta e sobre o próprio fazer literário. Marina, alvo de sua atenção, mescla-se aos sentidos da produção artística segundo a metodologia de uma estética urbana:

Aquilo viera pouco a pouco sem a gente sentir. Naturalmente gastei meses construindo esta Marina que vive dentro de mim, que é diferente da outra, mas se confunde com ela. Antes de eu conhecer a mocinha dos cabelos de fogo, ela me aparecia dividida numa grande quantidade de pedaços de mulher, e às vezes os pedaços não se combinavam bem, davam-me a impressão de que a vizinha estava desconjuntada. Agora mesmo temo deixar aqui uma sucessão de peças e de qualidades: nádegas, coxas, olhos, braços, inquietação, vivacidade, amor ao luxo, quentura, admiração a D. Mercedes. (p. 64-65; os grifos são meus)

Marina é uma e outra: é, em alguns momentos, menos uma mulher e mais um efeito de construção discursiva. Um dia, estando no quintal, ela aparece a Luís da Silva por trás da cerca. O ar, de repente, amolece:

Tive a impressão extravagante de que o ar havia tomado de repente a consistência mole e pegajosa de goma-arábica. Nesse ambiente gelatinoso Marina se movia, nadava, desesperadamente bonita, o peitinho redondo subindo e descendo, a querer saltar pelo decote baixo, pimenta nos olhos azuis, os cabelos de fogo desmanchando-se ao vento morno e empestado que soprava dos quintais. (p. 57-58)

No quintal, a cidade se rarefaz, dilui sua carga significativa e fundante; e, talvez por isso, imagens vívidas fecundem esse momento. Luís da Silva, tomado por um ím- 
5 "Do ponto de vista técnico, o cubismo é uma fragmentação do espaço tridimensional construído a partir de um ponto de vista fixo; as coisas existem mantendo relações múltiplas, umas com as outras e mudam de aparência de acordo com o ponto de vista escolhido para olhá-las" (SYPHER, 1980, p. 196; o grifo é meu). A explicação dada por Sypher para a experiência cubista coincide termo a termo com a pintura que Luís da Silva faz de Marina. peto, constrói, como aconteceria a um romântico inebriado, uma Marina fragmentada, como as heroínas românticas, aqui atualizada por certa tendência cubista de realização literária. Assim, surge, mas não sem espanto para Luís da Silva, uma Marina metonimicamente desenhada, em uma lógica que já não é a da pintura renascentista:

Veio-me o pensamento maluco de que tinham dividido Marina. Serrada viva, como se fazia antigamente. Esta idéia absurda e sanguinária deume grande satisfação. (p. 58)

Isso é prazer estético, prazer advindo da realização de uma construção e da iniciativa de escolhas do ângulo de visão do espectador para melhor fruir a imagem. ${ }^{5}$ $E$, a partir daí, surge-lhe o quadro cubista, sem as notações da perspectiva clássica:

Nádegas e pernas para um lado, cabeça e tronco para outro. A parte inferior mexia-se como um rabo de lagartixa cortado. Mas eu não reparava na parte inferior, que tanto me perturbara: recebia as faíscas dos olhos azuis e desejava enxugar com beijos a saliva que umedecia os beiços um pouco grossos da minha amiga. (p. 58)

A imagem de Marina é um apanhado solto de nádegas, pernas, olhos e lábios que não se conectam entre si a não ser pela visão do espectador que estabelece as escolhas de relações entre as partes. Fora do quintal, porém, Luís da Silva é o romântico ressentido, carente das origens, de mal com a civilização - aliás, nem o campo escapa a seus ressentimentos. Por isso é que, fora do quintal, Marina lhe aparece outra, sem a ponta de idealização de antes, retornando como uma mocinha leviana e burra:

Estúpida. Lia as notas sociais, casamentos, batizados, aniversários, coisas deste gênero. Estúpida. (p. 40)

Mas, no quintal, Marina transfigura-se objeto de de- 
leite estético e de prazer erótico, a mesma Marina que depois de um passeio atormentado que ele faz pela periferia da cidade, seguindo-a até a casa da parteira que realiza o aborto - vai levá-lo, enfim, ao desespero motivado pelo ciúme e, conseqüência imediata disso, à eliminação brutal do rival.

\section{Águas infindas}

Deixei para o final do artigo a análise da presença das águas, líquidos e derivados nessa narrativa. Pode-se dizer que Angústiaé uma narrativa molhada. Atravessam todo o romance, para ficar com o mais flagrante, a água do poço e a água das garrafas e dornas, cuja menção, insuspeitadamente e abruptamente, aqui e ali, já constitui outra interrupção ao fluxo natural da narração; também, dentro desse contexto de sentidos, a água de chuvas finas, líquidos de toda espécie como suor, lama, azeites, aguardente. No mínimo, quando nada parece motivar a presença de líquidos nas imagens criadas, aparecem, por exemplo, a voz de Julião Tavares, que é "oleosa" (p. 91), algo aborrecível, ou algo como "as frases iam pingando no papel" (p. 44), indiciando o trabalho da escrita, lento, parcimonioso, meio monótono. Eis um exemplo mais seguro dessa relação:

Como era grande o calor, abri a janela do quintal. Uma baforada de ar quente bateu-me no rosto. Debrucei-me e distraí-me acompanhando com a vista os movimentos da mulher que lava garrafas. $O$ gato pulou de um galho da mangueira, saltou o muro, trepou num monte de lixo e cacos de vidro. O homem triste andava entre as pipas, debaixo do telheiro, a encher dornas. (p. 53)

Essa mesma imagem retorna várias vezes, obsessivamente:

Chap, chap, chap. Era o vascolejar da água nas garrafas. Líquido se derramava: o homem triste enchia dornas. D. Adélia tossia no banheiro, espremendo roupa. E Vitória, na cozinha, cantava [...]. (p. 55) 
A imagem intromete-se onde menos se espera, não tem conexão com o andamento normal da narrativa; é uma espécie de subtexto que caminha ao lado do texto central, cortando-o por todos os lados, adicionando-lhe sentidos:

Entrei na sala de jantar, bebi um pouco de aguardente, fiquei um instante olhando, por cima do muro, a mulher que lava garrafas e o homem que enche dornas. (p. 75)

Mesmo depois de ter cometido o crime e ter entrado num estado de letargia, cansaço e entrega de si mesmo, Luís da Silva não deixa de registrar a cena recorrente:

Desejei ver Seu Ivo, pensei em oferecer qualquer coisa a Seu Ivo. Isto me aliviaria. As alfaces no canteiro amarelavam. O homem triste enchia dornas. A mulher magra agitava garrafas e sacolejava-se como se tocasse ganzá. Nenhuma novidade. (p. 199)

A seqüência narrativa, verdadeiro leitmotiv do romance, mistura-se ao delírio de Luís da Silva:

Moisés e Pimentel me seriam desagradáveis naquele momento, mas a companhia de Seu Ivo me daria prazer. Subitamente imaginei que o homem triste e a mulher magra me espionavam. Afastei a cadeira para não ver o homem que enche dornas e a mulher que lava garrafas, continuei a tarefa. (p. 199-200)

Espécie de linguagem mítica, pelo seu simbolismo e pela seu movimento circular, a água escreve e dilui os contornos da cidade, alaga e perfaz a narrativa. Esta é a cidade literária, cujas ruas e becos são ensombrados, anseiam por libertação, retorno ao primevo, quando é ela mesma, a cidade, que produz o afastamento, a fragmentação e a dilaceração do eu. O elemento externo, que é a cidade e esse mundo estranho da urbanização, transforma-se, durante o processo de composição da narrativa, na opacidade do cenário e da mente da personagem. O ele- 
mento mediador da transformação são as águas, que correm por todos os lados do texto, fundindo o que é circunstância exterior ao que é alma:

Se Marina voltasse... Por que não? A água lava tudo, as feridas cicatrizam. Não valia a pena pensar no outro. (p. 99, o grifo é meu)

Como numa espécie de autocitação, o narrador repete a frase em outro momento do texto, aquele em que, após seguir Marina e esperá-la em um bar em frente à casa da parteira onde ela fizera o aborto, anda pelas ruas da cidade:

- Puta!

Os beiços de Marina estavam como os de uma defunta, os olhos procuravam socorro, e eu cravava as unhas nas palmas das mãos, mordia a língua por haver deixado escapar mais uma vez a injúria que nada significava. Deu-me uma tontura, cambaleei. [...]. - "A água lava tudo, as feridas cicatrizam." Repeti mentalmente esta frase, mas não pude saber de quem era ela. (p. 168)

A cidade é testemun ha mas principalmente determina a psicologia da escrita e da personagem. Uma cidade que as águas invadem, ora em estado líquido, ora em estado gasoso, transtornando a feição realista do romance, de modo a tornar os seres difusos e escorregadios e a perspectiva clássica, ameaçada:

A necessidade de fumar atrapalhava-me os movimentos. Julião Tavares flutuava para a cidade no ar denso e leitoso. Estaria longe ou perto? Aparecia vagamente nos pontos iluminados, em seguida o nevoeiro engolia-o, e eu tinha a impressão de que ele ia voar, sumir-se. Um balão colorido em noite de São João, boiando no céu escuro. (p. 178, os grifos são meus)

A cidade, portanto, produz os sentidos do texto: a vaguidade causada pela penumbra da atmosfera, de tom quase onírico, por exemplo, foi necessária às determinações estéticas de Angústia, nessa pintura que Graciliano 
Ramos faz de Maceió, desrealizando-a, para adaptá-la aos seus desígnios de escritor - e, parece, não poderia ter sido de outro modo, sob pena de destruir a unidade do livro e as intenções da narrativa.

Foi assim que Graciliano procedeu para compor Luís da Silva e o redemoinho de suas lembranças, como também para adequar o tom da narração à violência contida do narrador, a qual, num dado momento, explode e faz romper os diques represados. Após assassinar Julião Tavares multiplicam-se as imagens de coisas que, antes firmes e duras, se tornam moles e inconsistentes, como se a água - líquida ou gasosa - tivesse, numa síntese perfeita entre o eu e a realidade, tornado flácido o mundo físico e social:

As paredes tornaram-se inconsistentes. [...] Um rumor enchia-me os ouvidos, burburinho que ia crescendo e me dava a impressão de que a casa, a cidade, tudo caía lentamente. As paredes se desmoronavam como pastas de algodão. (p. 197)

Enfim, o quintal não venceu a cidade, nem mesmo no romantismo, onde se pretendeu que a natureza revelasse sua face fundadora e produtora de sentidos, sem impedimentos e restrições. Assim como lá, a Natureza cede à Cidade - Peri precisou da civilizada Ceci para dramatizar a simbologia da nacionalidade, ainda que terminassem ambos boiando em uma folha de palmeira, como também Iracema precisou morrer para que o colonizador Martim levasse à frente o programa da constituição da raça, educando o filho mestiço - , com a diferença de que, na modernidade pós-baudelairiana, a cidade manifesta a força de sua crueldade e impõe o anonimato ao homem que passa, aturdido, por entre a floresta de símbolos que já não o reconhecem. A solidão de Luís da Silva é completa, sem Iracemas ou Cecílias. Sem água, sem descanso:

Se Vitória me trouxesse um copo de água... Ali com sede, morrendo, sem um diabo que me desse 
uma xícara de café, um copo de água! Embalava-me com isto: - "Sozinho, sozinho, morrendo à míngua, com sede." (p. 212)

A realidade é completamente adversa; nada o salva nesse final desolador. A cidade estava toda contra ele, apagando suas marcas, sua proteção. Águas infindas, águas que matam:

Alguns letreiros estavam raspados, outros desapareciam sob as manchas que as águas da chuva tinham produzido. (p. 212)

A ironia máxima do livro reside na utilização de um símbolo bíblico que se deixa corroer até a base, pois que não salva a narrativa nem recupera o tom sagrado das narrativas ancestrais ligadas ao mito. O espírito de Deus - como o copo de água que não vem (nem Vitória o pressente) - perde-se no emaranhado das coisas citadas, no vazio da Queda:

Albertina de tal, parteira diplomada. Escuridão. Um estremecimento, uma queda. Ia cair da cama, o chão se abriria, eu rolaria pelos séculos dos séculos fora disto. O espírito de Deus boiava sobre as águas. Livrava-me do susto, pouco a pouco ia resvalando no entorpecimento. Os caibros faziam voltas, as telhas se equilibravam por milagre. (p. 213, o grifo é meu)

O espírito de Deus mistura-se à lembrança súbita da Albertina parteira e à visão agônica de caibros e telhas que, no delírio, ameaçavam desabar. No entanto, por mais que a cidade moderna expulse o mito e o sacro, a narrativa, no ato mesmo de dizer, volve ao tempo de origem, como se procurasse, em meio à fragmentação, responder às inquietações humanas. Luís da Silva é um ser da busca permanente; sua narrativa é o atestado do sentimento de recuperação das falhas que sofre - falha de origem, falha de valor social, falha amorosa, falha de humanidade. As águas, águas infindas, que se vêem metaforizadas através do mergulho no poço, nos 
baldes, garrafas e dornas, no suor, na aguardente, na chuva e no azeite, são a marca do mito ${ }^{6}$ que luta em vão contra a racionalidade da cidade, reino do impessoal e do transitório.

Seria a literatura a modalidade de discurso na modernidade que, em meio à impessoalidade da cidade e da vida pública, procura interpretar o social como pessoal e subjetivo, carregado de paixões? A literatura seria, assim, a anti-República?

${ }^{6}$ Segundo o Dicionário de simbolos, de JuanEduardo Cirlot, as águas, "ilimitadas e imortais", seriam, entre outros aspectos, "o princípio e o fim de todas as coisas da terra" (CIRLOT, 1984, p. 62).

A narrativa de Angústia, ao dar papel fundamental ao elemento "água", fazendo suas associações com o desenvolvimento discursivo, de algum modo recupera sentidos míticos em meio à impessoalidade da cidade, como se, assim, visasse a reagir contra os discursos correntes. 


\section{Referências}

CANDIDO, Antonio. Fiç̧ão e confissão: ensaios sobre Graciliano Ramos. Rio de Janeiro: Ed. 34, 1992.

CIRLOT, Juan-Eduardo. Dicionário de símbolos. Trad.

Rubens Eduardo Ferreira Frias. São Paulo: Moraes Ltd ${ }^{a}, 1984$.

FERNANDES, Ronaldo Costa. Narrador, cidade, literatura.

In: LIMA, Rogério; (Org.). O imaginário da cidade.

Brasília: Editora da UnB; São Paulo: Imprensa Oficial do Estado, 2000. p. 19-36.

HALL, Stuart. A identidade cultural na pós-modernidade.

Tradução Tomaz Tadeu da Silva; Guacira Lopes Louro. 7. ed. Rio de Janeiro: DP\&A, 2003.

JAMESON, Fredric. $O$ inconsciente político: a narrativa como ato socialmente simbólico. Tradução Valter Lellis Siqueira. São Paulo: Ática, 1992.

LOBO, Luiza; FARIA, Márcia Gonçalves S. (Org.). A poética das cidades. Rio de Janeiro: Relume Dumará, 1999.

RAMOS, Graciliano. Angústia. 15. ed. Rio de Janeiro:

Record; São Paulo: Martins, 1975.

SENNETT, Richard. O declínio do homem público: as tiranias da intimidade. Tradução Lygia Araujo Watanabe.

São Paulo: Companhia das Letras, 1988.

SYPHER, Wylie. Do rococó ao cubismo na arte e na literatura. Tradução Maria Helena Pires Martins. São Paulo: Perspectiva, 1980. 